\title{
The Future of Teaching English in Saudi Arabia
}

\author{
Turki Assulaimani \\ Department of European Languages and Literature, Faculty of Arts and Humanities, King Abdulaziz University, Saudi Arabia
}

Copyright@2019 by authors, all rights reserved. Authors agree that this article remains permanently open access under the terms of the Creative Commons Attribution License 4.0 International License

\begin{abstract}
Even though the future is unknown and may be hard to forecast, its formulation can still be influenced by the making of some decisions in the present time (Amara, 1981). This article reviews the TEFL situation in Saudi Arabia in the past and the present, and offers some recommendations for improving it in the future. These recommendations will include policy and school-based levels. The article will include discussions about the Saudi government's strategies of enhancing the education system through Information Communication Technology (ICT), future teaching systems, teachers and students' roles, future teacher education, important issues in assessment as well as recommendations for policy regarding critical issues for EFL instruction in Saudi Arabia, including a detailed examination of the Tatweer Project, which is the Saudi Arabian government policy to be implemented between 2013-2023, with the aim of developing public education in Saudi Arabia.
\end{abstract}

Keywords Saudi Arabia, TEFL, Tatweer, English, ICT

\section{Introduction}

People generally accept that it is impossible to predict the future with accuracy. Nevertheless, it is certainly possible to predict possible outcomes given past and current experience. It is important to build on the successes and avoid the obstacles identified in past to improve the future. Education draws on the past, while it is performed in the present and is meant to inform the future (Haapala, 2000). Thus, contemplating the future of English as a Foreign Language (EFL) Education in Saudi Arabia is an important aspect of Saudi education since it can help the educational system fulfill its legal and moral obligations towards the students, as well as address the anticipated needs of other stakeholders involved in the educational process. One of the main aims of the studies concerned about the future of education is to facilitate the envisagement, construction and application of preferred futures, which will, in turn, clarify the thinking, highlight priorities, and then focus the planning on ways of accomplishing these optimistic visions (Hicks, 2002). This article will introduce the Tatweer Project, which is the Saudi government's plans and policies to be implemented over a decade with the aim of developing public education in Saudi Arabia, from 2013-2023.

Being mindful of the wide range of potential future possibilities informs and influences the decisions that individuals and organizations make in the present (Haapala, 2000). The need for discussing the future of education arises from the fact that through the predictions of possible consequences and the assessment of these potential consequences individuals and organizations can arrive at intelligent and informed decisions with regard to future planning (Bell, 2001).

Several scenarios have been proposed for the future education worldwide from lifelong learning (Mercer, 1999) to personalization of learning (Levin \& Kojukhov, 2013), and even 're-schooling' scenarios focusing on maintaining schools as learning organizations where different types of innovation, creative experimentation as well as Information Communication Technology (ICT) enhanced learning is emphasized (OECD, 2001). A closer look at the educational polices in Saudi Arabia for the past decade or two shows that the current and future vision for education in the Saudi context, nonetheless, has a more notable focus on the ICT-enhanced re-schooling scenario.

\section{Technology and Education in Saudi Arabia}

Till recently, policies related to the use of technology in education in Saudi Arabia have typically been general in nature, and have not focused on EFL teaching and learning in particular. They have indirectly affected the EFL instruction, however, as a part of the new trend of integrating technology into almost all the school subjects in the Saudi educational system. For example, in 1991, the Ministry of Education (MOE) introduced a computer-based course to the compulsory curriculum for the secondary school level for the boys, and later for the girls as well. In the second phase, MOE started promoting 
the use of computers and technology in the teaching of different school subjects through the employment of different schemes (General Directorate for Planning, 2005). By the year of 2003, ICT was a compulsory subject in both male and female secondary schools as well as in the boys' primary schools. Later, the Ministry launched three national projects to further enhance the use of ICT in schools. Two of these projects were "Watani" and "Jehazi", which aimed at providing training for teachers on the use of ICT, providing personal laptops for every teacher and family at very competitive prices with easy-to-pay installments, and promoting the use of computers and technology in all subjects in Saudi schools to connect the different stakeholders involved in the educational system, including students, teachers, administrators and parents through the use of 'The School Net' (Al-Madani \& Allaafiajiy, 2014). The latest initiative by the Saudi government that clearly highlighted the importance of ICT integration was "Tatweer", which can be translated into English as 'development or improvement' of Education. According to Al Harby (2014, p. 33), “King Abdullah’s Public Education Development Project (Tatweer) which was seeking to equip classrooms with ICT equipment including laptop computers, projectors, and interactive whiteboards, was launched with a budget of 9 billion Saudi riyals (around 2.5 billion USD) over a six-year period”.

The second phase of the aforementioned project "Tatweer" was the latest and one of the most important initiatives launched in cooperation with MOE in 2012. Its discussion in detail is presented in the following section.

\section{Current Situation}

The Tatweer Project outline sketches the plans and policies to be implemented over a decade with the aim of developing public education in Saudi Arabia. It spans between the years 2013 and 2023, and it is divided into two five-year action phases. This project looks at developing EFL teaching and learning as one of the most important areas to be enhanced following the Tatweer project course of action. The enhancement of the Saudi students' English language skills is outlined to be achieved through nine phases:

1 Constructing a new high quality EFL curriculum that rises to the new national pedagogical standards.

2 Providing continuous EFL teacher training on the most up-to-date EFL teaching methods and strategies to cope with the skills needed by students in the 21st century.

3 Creating teacher training networks to enable EFL teachers to exchange teaching tips to continuously improve their teaching practices.

4 Enabling competent experienced EFL teachers to develop effective teaching strategies then share them with other teachers.
5 Training EFL teachers to utilize ICT in their teaching and in their students' learning practices.

6 Developing EFL teachers' skills in creating opportunities for their students to communicate with native English speakers (e.g. through online communication platforms).

7 Developing extra-curricular teaching resources, e.g. digital resources, to assist learners and teachers in their EFL teaching-learning process.

8 Developing a new cooperation with higher education institutes to assist in developing, applying and informing schools about the most recent and effective EFL teaching strategies.

9 Expanding the use of technology to create nationwide online-EFL-teacher communities dedicated to sharing the most effective teaching strategies and resources on both school and education directorate levels.

(National Strategy for Public Education Development, 2012, p. 51)

Scanning through these nine phases, one can notice that each one of these phases fall under one of three major streams of development, namely ongoing teacher training and professional development, employment of new and effective research-based pedagogies and teaching strategies, and major reforms to the traditional EFL curriculum through ICT integration into English teaching and learning. The urgency for curriculum reforms is clearly emphasized as the first goal of the EFL Tatweer scheme, and is embodied implicitly in the following eight phases of the Tatweer Project. Improving the pedagogical knowledge and practice of the English teachers is another clearly pronounced central goal of the Tatweer Project and appears to aim for the provision of life-long learning for teachers to equip them with the knowledge and skills needed for EFL instruction in the $21^{\text {st }}$ century. One way of achieving this is through ongoing teacher training programs on the most recent, innovative and effective methods and techniques of English language instruction as well as ICT integration inside and outside the classroom. The development of such teaching methodologies is suggested to take place in cooperation with experienced EFL practitioners and specialists who have accumulated ample skills and knowledge throughout their careers, and can assist in suggesting some attainable learning outcomes and recommend the best and most appropriate ways of achieving them. Such suggestions are to be based on the careful evaluation and analysis of the students' levels, abilities and needs as well as the available resources. This can personalize learning and turn it into a more student-centred and meaningful experience. According to Zeichner, Payne and Brayko, future English teachers need to be "active participants in the planning, instruction, and evaluation activities related to a course, thereby creating more authentic, acceptable, and accessible possibilities for inclusion of teachers' expertise.” (2015, p. 127).

Additionally, future teaching methodologies and 
training programs are to be based on the most recent studies provided by relevant educational research bodies in local and international universities and other relevant higher education institutes. It may also be appropriate for such programs to be specifically tailored to address the relevant needs and suit the available resources in Saudi schools by dedicated teams of experienced teachers, school principals, and even exceptional students who may liaise between schools and education directorates nationwide, as well as between schools and directorates, research centres and the MOE. These teams can provide schools and teachers with the most contemporary EFL teaching methods and strategies in the field, and at the same time communicate the schools' and teachers' views and concerns, as well as the resources required for the most effective implementation of the current and suggested teaching methods to the MOE, which can also be included in the designing and development process of the English curriculum later.

The third area of focus in relation to enhancing English education in Saudi Arabia and an accentuated recommendation throughout the lengthy (110 pages) Tatweer Project outline is the promotion ICT integration into all school levels and subjects, including TEFL. This, however, should not stop at the provision of computer and Internet services in schools, or the development of communicative and interactive online resources accessible by both teachers and students around the nation. Rather, it relates to the need for promoting learners' autonomy and extending the language learning process beyond the walls of the classroom.

\section{Technology-enhanced Language Learning}

ICT use in education has been documented to have substantial benefits to both teaching and learning. It offers teachers and students access to an enormous bulk of knowledge and information, and provides them with the opportunity of transcending the borders of their classrooms to an almost endless virtual space of learning through communicating with others online, and through accessing and participating in relevant educational and non-educational websites and forums (Baines, 2005). This is particularly useful for learners of English in EFL contexts, such as Saudi Arabia where direct contact with English native speaker is rather rare and difficult. Moreover, the Internet provides English language learners with a wide range of authentic texts and resources, which significantly undermines the problem of not being able to have access to print materials in English which has been a problem faced by many L2 learners around the world. Not only that, but technology-enhanced instruction has the potential of revolutionizing the educational process through promoting autonomous learning among students, and changing the role of the teacher from being the authoritative expert inside the classroom to that of a facilitator, coordinator and collaborator of their students learning (Al-Hadlag, 1998; Wasserman \& Millgram, 2005).

In a study conducted by Wasserman and Millgram (2005) following an assessment of a program of computerisation in some schools, many benefits were reported including: improvement of cognitive abilities, reinforcement of weak students, and expansion of knowledge, diversification of teaching strategies and methodologies, and increase in students' motivation to learn. Comparable research in the Saudi context yielded similar results. Several Saudi studies have shown positive effects of using ICT on EFL teaching and learning. For example, studies have found that online reading has an overall positive impact on the Saudi students' reading comprehension ability (Abanomey, 2013), writing literacy and attitudes toward academic writing (Al-Jarf, 2002; 2004) as well as grammar achievement (Al-Jarf, 2004). Using Computer-Assisted Language Learning (CALL) was found to lead to more exposure to English and, in turn, positively affect students' performance (Al-Mekhlafi, 2006). Moreover, computer mediated communication (CMC) technology or Learning Management Systems (LMSs), i.e. blackboard, proved to be very useful in providing Saudi EFL learners with the socio-linguistic interaction and emotional support needed to enhance their linguistic writing abilities and critical thinking skills, as well as improving their overall attitudes towards academic writing in English (Fageeh \& Mekheimer, 2013). Using the Blackboard-oriented, online dictionary-based method for presenting etymological analysis of new vocabulary also proved to be more effective in developing vocabulary building skills and inducing positive attitudes towards vocabulary learning than traditional teacher-centred and paper dictionary-based vocabulary instruction (Fageeh, 2014). It was also reported by Ibrahim and Yusoff (2012) that the use of wikis in an EFL blended-format course improved the learners' speech delivery and speaking skills.

The bulk of research on the positive effects of ICT use in education has evidently convinced many Saudi teachers and academics of the virtues that a proper utilization of ICT in teaching can have on EFL instruction. Alshumaimerie (2008) indicated that Saudi teachers with CALL training reported positive attitudes towards using technology inside the classroom. Al-Jabry, Salahuddin and Al-Shazly (2014) reported that even Saudi students had favourable attitudes towards learning using blackboard and that their learning outcomes proved the "effectiveness of the Modern Literary Movements course delivered online" (p. 85). Similar findings were reiterated in numerous other Saudi studies (see Al-Jarf, 2004 for a detailed review). Other studies add that teachers consider the use of computer and Internet not only as a more enjoyable and effective teaching method inside the classroom, but also affirm that it can more 
importantly provide students with resources to improve their English learning anytime and anywhere (Al-Mukhallafi, 2014). The level of expertise and training in ICT as well as the experience in English teaching were found to correlate positively with teachers' use of these resources during their teaching (Alshumaim \& Alhassan, 2010). These studies illustrated that if appropriately implemented, specific technologies can, indeed, be beneficial in changing the perceptions of teachers and learners towards the study of English, which is an important first step towards improving their English language proficiency.

The MOE's pushing towards the integration of ICT in education in Saudi Arabia is understandable given the positive outcomes that technology-enhanced instruction has been linked with in relevant Saudi and cross-cultural literature. However, a number of issues must be addressed in order to ensure that educational system benefits from the potential of ICT integration. Al-Showaye (2002) investigated the use of ICT in intermediate and secondary schools in Saudi Arabia and reported that several barriers stand in the way of experiencing the full potential of technology-enhanced education in Saudi schools including: lack of time and technical support, inadequate computer facilities, large class sizes and lack of teachers' training. Poor Internet services and computer facilities in technology-enhanced instruction are regarded as significant potential disruptions to the students' learning experience that can impact the whole process of learning negatively (Galusha, 2011).

Even with the optimum integration of ICT in education in Saudi Arabia, many educationalists emphasize the fact that ICT is not a magical wand that can fix all problems faced by students and teachers inside the classroom. It is important to remember that ICT is only one of numerous factors influencing the teaching-learning process, and that the positive effects of integrating it into the educational process may only be subtle and indirect. According to $\mathrm{Al}$ Harby (2014, p. 35), "changes in classroom practices will not occur simply because ICT is more available in the classrooms”. Fageeh (2011, p. 22) also adds that technology in itself "does nothing to improve student academic achievement, but it can bring about changes in motivation and attitude, which are instrumental in enhancing academic achievement." The introduction of ICT in Saudi schools is not sufficient in itself for making a real positive change in the Saudi educational system; rather, a better way to accomplishing the desired changes is through looking at education as a complex process which involves many factors affecting each other and being influenced by each other (Abdulkareem, 2002; Al-Saleh, 2002).

\section{The Future of EFL Curriculum}

Curriculum design generally refers to the construction of content and how this content is delivered to the students. The latest initiative by MOE in relation to promoting ICT use in TEFL in Saudi Arabia based on the Tatweer Project recommendations was in 2014 with the introduction of the new technology-enhanced English language curriculum. The English textbook series prescribed for primary schools is entitled "Get Ready"; the one for intermediate schools is entitled "Lift Off", while the one for secondary schools is entitled "Flying High". With every free English Pupil's Book, which combines the textbook and the workbook, students receive an audio $\mathrm{CD}$ for listening. All of these materials as well as other suggested supporting training and teaching resources are provided for the teachers on a website devoted to each of the previously mentioned six-level series, i.e., to each of the schooling levels in the Saudi educational system (see for example www.macmillanenglish.com/GRSA for more information about the Get Ready series).

The introduction of the newly designed English textbook series appears to be the first step towards the development of technology-enhanced English instruction in Saudi Arabia. The gradual establishment of new learning habits among Saudi learners of English is a priority in order to keep up with and make the most of the new age of tech-oriented teaching-learning trends. A much-needed next step is the integration of not only audio CDs in the English language curriculum in Saudi Arabia, but of a more consistent integration of computers, smartphones and the Internet into the teaching-learning habits of Saudi learners and teachers of English. One of the main weaknesses of English instruction in Saudi Arabia is its sole focus on rote memorization in teaching English (Bawazeer, 2015). The strong tendency of a considerable number of Saudi teachers of English on emphasizing the role of memorization in L2 learning is a result of the English teaching philosophies and practices that these teachers have mostly been exposed to during their English learning process and their English teaching training, which have strongly been influenced by the traditional methodologies, e.g. Grammar Translation and the Audio-Lingual approaches of second language learning.

Utilizing the Internet and Smartphones can promote autonomy, creative analysis and independency while discouraging rote memorization learning (Bawazeer, 2015; Communication and Information Technology Commission, 2013). It also aims at incorporating what the learners already have and use in their natural environments in more productive ways and into their English learning habits (Sayed-Mouchaweh \& Lughofer, 2012). Before the Internet became widespread in recent years, the most usual way for EFL learners to immerse themselves in the target language was through traveling to English-speaking countries. Tens of thousands of Saudi students have recently started receiving their undergraduate and postgraduate studies in English speaking countries through the late King Abdullah Scholarship Program. Nevertheless, 
this privilege is not viable for all Saudi learners, especially the younger ones. Fortunately, however, "[l]earners do not have to do this now as they can create virtual immersion situations via the Internet” (Bawazeer, 2015, 40). English teachers can play a significant role in informing their students about the best English learning websites and smart phone applications; teaching them the most useful techniques and strategies of incorporating these ICTs into their daily routines to improve their English proficiency; and facilitating virtual immersions situations for their students where they can communicate with English native speakers to ensure their maximum exposure to English both inside and outside the classroom.

\subsection{Future Teaching Systems}

Technology-enabled teaching was reported to be successful in motivating language learners, improving their L2 achievement, and assisting them in developing successful strategies in L2 learning (Jelfs \& Whitelock, 2000). Utilizing Learning Management Systems (LMS), e.g. blackboard, in the Saudi educational system can be a beneficial tool towards the development of education in Saudi Arabia, including English language teaching. Noor is an online system that was introduced to the Saudi education in 2010 to provide some basic online services to the teachers, students, and their parents. For example, it allows teachers in Saudi schools to share the midterm and final exams' grades with their students and their parents online. The system offers some basic organizational services to its users, but it does not have any online instruction-related foci. It seems, however, like a first step towards the development of a more comprehensive LMS, which accommodates a varied range of interactive tools facilitating instruction-related communication and materials sharing between teachers and students.

More advanced LMSs like Blackboard are currently being used in some Saudi universities to improve the quality of interactive teaching, mostly with distance learning students, and serve as an indispensable tool for organizing communications between students and instructors; and between students themselves. Utilizing such resources in all the higher education institutions as well as in schools throughout Saudi Arabia may offer great benefits to both students and teachers.

Typical LMS provide a number of specific tools that support diverse functionality ranging from "materials management" to organize interactions between the student and the course content (e.g., syllabus, course readings, lecture slides), "interactive teaching" to organize interactions between the instructor and students (notifications, assignments, quizzes), and "peer learning" to organize interactions between students (peer review, group projects, student wikis). (Lonn \& Teasley, 2009, p. 686)

In the hope of a more effective integration of technology use in the English curriculum, and shifting from teacher-centred language learning towards more student-centred approaches many future EFL teaching scenarios have been proposed. Sandi (2013) contended that the introduction of Computer-Assisted Language Learning (CALL) into English teaching in Saudi Arabia could have a positive impact on the teaching and learning process given that the teachers are appropriately trained on making the best use of the most up-to-date technologies. However, it is noteworthy that utilizing paradigms that significantly undermine the role of the English teacher inside the classroom and within the learning-teaching process might not be the best strategy in the Saudi context where instruction inside the classroom has almost been solely dependent on the teacher. The lack of formal classroom instruction may negatively interfere with the students' motivation and progress, and would expose them to various environmental distractions as well (Galusha, 2011). Thus, it may be more appropriate to attempt to gradually utilize some forms of blended-learning (where both textbooks and digital/online resources are used) in the Saudi education in order to reap the benefits of both CALL and face-to-face learning programs while offsetting their shortcomings.

The new English curriculum is a step towards the development of the technology-enhanced instruction or blended-learning paradigm in which ICT is integrated into the curriculum to be used alongside the English textbooks inside and outside the classroom. The different book series intended for the different school levels are developed by McMillan Education and have been written specifically for Saudi pupils to provide them with solid grounding in English language proficiency using English Pupil's Books, which combine the textbook and the workbook, audio CDs for listening, and other teaching resources provided on a website devoted to each of the six-level courses. An integration of more use of computers, smartphones and the Internet into the teaching-learning habits of Saudi learners and teachers of English, and the development of a more advanced forms of LMS are likely to be present in the Saudi EFL curriculum in the next few years.

\subsection{The Future of EFL Teacher Education}

Teachers' roles and responsibilities in the new educational system need to be redefined in consistence with the new vision for education in Saudi Arabia, and English teachers' roles and responsibilities are no exception. Many would agree that a good language teacher is one who is both linguistically and pedagogically competent. Recent discussions seem to place more focus on the later (McDonald, Kazemi \& Kavanagh, 2013). Grossman (2008, p. 185) adds:

Over the past 50 years, research on teaching has moved from looking primarily at teacher characteristics-such as enthusiasm or authoritarianism-to looking at teaching behaviors, teacher decision making, teacher 
knowledge, and teacher reflection and dispositions. Each of these ways of looking at teaching, in turn, influenced how we think about preparing teachers . . . Teaching, at its core, is an interactive, clinical practice, one that requires not just knowledge but craft and skill.

Improving teaching and learning to teach are two tightly intertwined tasks. Some approaches of preparing teachers and helping them be more conscious of their shortcomings and more in control of their teaching practices can include ongoing assessment and enhancement of their knowledge including technology use in language instruction, development of generic and subject-specific observation schemes, and video analysis of classroom teaching. The formative nature of discourse analysis of classroom interactions captured through video can help teachers note, critically examine and reflect upon their teaching, then understand how to achieve their desired teaching identities to improve their own and their students' teaching-learning experience (Schieble, Vetter \& Meacham, 2015).

Another way to assess teachers' performance and ensure that it is at an appropriate level is to improve the quality of instruction, provide professional assistance when needed through the introduction of efficient teacher performance appraisal (TPA) strategies, and making them an indispensable part of the Saudi educational system. Previous research on the topic of TPA revealed some problems with regard to the subjectivity and abuse of such tools by some incompetent evaluators, which led in many cases to a considerable level of dissatisfaction among the teachers with the evaluation process and with potential professional benefits of TPA (Adams, 2009; Alicias, 2005, as cited in Al-jarf, 2015). Yet, several suggestions have been proposed by many researchers in hopes of gaining more reliable and objective teacher evaluations including training raters (Weast et al., 1996), using teachers' performance constructs, which can help teachers identify their problems and better their performance (Yanghong \& Chongde, 2006), and using electronic teacher evaluation systems and TPA rubrics, i.e. rating guides consisting of pre-determined criteria used in evaluating performance levels and skills (Al-jarf, 2015; Reddy \& Andrade, 2010). It is highly recommended that such considerations be taken into account and get incorporated in future TPA rubrics assessing teachers' performance and making changes when and where necessary based on the TPA results.

Furthermore, ongoing teachers' training on the use of ICT is essential to optimize the potential of the newly designed technology-enhanced English curriculum. Many Saudi instructors including university staff members expressed their lack of training on the use of new technologies inside the classroom (AbdulCalder \& Anthony, 2014). Albalawi (2007) reported that the instructors who received training on the use of technology in teaching demonstrated more willingness in utilizing and developing blended learning materials. Only through the use of appropriate teaching methodologies, and the development of proper training for English teachers on the most effective and efficient ways of utilizing ICT in the teaching-learning process inside and outside the classroom are the current and future English teaching practices going to yield the anticipated positive outcomes. Convincing English teachers of the usefulness of using ICT in their teaching, and informing them about the most suitable ways of incorporating it into their teaching and testing practice to improve their teaching and conserve their time and energy can, in turn, positively affect the students' views on the role of ICT in learning English, change their learning habits, and eventually improve their English proficiency levels towards the desired levels.

\subsection{The Future Classroom and the New Teachers' and Students' Roles}

ICT revolution is transforming the field of education leaving educational systems outside this change "to marginalisation or even extinction” (Aviram, 2000, p.333). Saudi research findings illustrate that the impact of technology-enhanced education is yet to rise to the expectations, however (Aljohani, 2006). ICT applications inside the classroom work best when optimal conditions are in place to support them (Roblyer \& Doering, 2010, p. 33). Appropriate use of ICT in schools is likely to promote autonomy in students, enhance efficiency, and extend opportunities for both teachers and students since its proper utilization inside the classroom can be similar to having an extra teacher or more in one classroom (Condie \& Simpson, 2004). It is anticipated that the apt integration of technology in English instruction is going to lead to several changes in the current roles of teachers and learners in Saudi schools.

To achieve an effective incorporation of technology use in English instruction, it is essential to offer appropriate training programs to both teachers and students on how to make the best use of the new technologies they get introduced to in schools. Only by having appropriate competence levels with regard to the use of advanced technologies can the potential of using online platforms for teaching and learning be maximized (Stephens, 2007). Particular attention has to be payed to students during this process, which would gradually lead to the desired personalisation of educational targets according to the students' needs, knowledge, skills, and emotions.

In an ICT enhanced educational system, teachers are expected to lose their traditional role of being the main source of information inside the classroom, and are likely to assume a role more similar to that of an enabler, adviser, observer, evaluator, facilitator, stimulator, motivator, and a participant (Al-Qahtani, 2006). Moreover, students are becoming experts on the use of technologies, which in itself is creating a need for instructors to become more tech-savvy in order to keep up with their students' skills and inspirations (Black, 2010). 
However, the focus on incorporating ICT in English teaching, albeit important and anticipated to induce some good results, should not divert our attention from implementing reforms to the other aspects of the common currently adopted teaching practices in the majority of English classrooms in Saudi Arabia. It is important to ensure that English teachers are able to impart the relevant and appropriate knowledge and skills to their students in the most effective and efficient ways. Future English classrooms should encourage more student talking time and less teacher talking time, which should consequently turn students into active agents in their own learning instead of being passive receivers. Such goals can be accomplished through promoting communicative language teaching focusing on cooperative learning and other student-centred methodologies.

Communicative language teaching (CLT) which dates back to the 1970s has proved its effectiveness over rote learning methodologies in studying English as a discourse and focusing on teaching students how to communicate and negotiate meaning effectively instead of learning lists of words or sentence structures (Hutchinson \& Waters, 1987; Widdowson, 1983). CLT practices are still not sufficiently or appropriately used in the majority of English classrooms in Saudi Arabia. Unfortunately, most of the English teachers still rely heavily on the traditional approaches of English teaching and do not integrate enough cooperative learning activities into their teaching practice.

Cooperative learning is usually defined as the instructional use of small groups of students who engage in face-to-face collaborative and mutually helpful interactions to maximize their own and each other's learning, complete a task, or achieve a common goal in an atmosphere which promotes interdependence and individual accountability as well as group processing (Artzt \& Newman, 1990; Davidson, 1990; Johnson, Johnson \& Smith, 1991). The use of cooperative learning has its well-documented positive impact on both the academic and affective domains inside the classroom (Cuseo, 1992). Cooperative learning has been documented to lead to more student participation and better student learning outcomes (Al-Sheikh, 2015). English teachers should incorporate different collaborative forms of problem-based and project-based learning activities into their teaching, i.e., activities in which language learners are presented "with an engaging problem, question, or puzzle . . . then discover course concepts for themselves as they explore the problem" (Anderson \& Lawton, 2007, p. 43, as cited in Iakovos, 2011). The use of such teaching methods would require students to use higher-level thinking skills, which are likely to result in effective and long-lasting education. Furthermore, such teaching practices foster critical thinking; stimulates active learning; and is likely to help language learners develop their English language skills accordingly.
One of the most important roles of the future EFL teachers is to positively influence the learning habits of their students inside and outside the classroom. Teachers should foster teaching practices that actively aim at developing the higher analytic skills of their students. According to (Iakovos, 2011, pp. 82-83),

teachers should help students shift: a) from guessing to estimating, b) from preferring to assessing, c) from grouping to classifying, d) from believing to assuming, e) from interring to inferring logically, f) from associating concepts to grasping principles, g) from noting relationships to noting relationships among relationships, h) from supposing to hypothesizing, i) from offering opinions without reasons to offering opinions with reasons, and $\mathrm{j}$ ) from making judgments without criteria to making judgments with criteria (Lipman, 1984, 1988).

It is important to note, however, that the incorporation of cooperative learning and other student-centred teaching approaches in the EFL classrooms in Saudi Arabia is not simply a matter of convincing teachers of the potential benefits and usefulness of employing such teaching methods. Training teachers to change their English language teaching practices towards the adoption of activities that encourage more student involvement inside English classrooms is not enough either. A shift from the current lecturing teaching style towards one that integrates the promotion of both cooperative learning, e.g. pair and group activities, and the activation of students' critical thinking abilities within a technology-enhanced instructional setting entails a transformation in the whole classroom structure. The current structure, design and physical space in Saudi classroom do not accommodate for such teaching practices. According to Parris, Estrada and Honigsfeld, (2016, p. 16), "in a digital learning classroom, the physical space is set up to allow for movement among students as they actively work within the classrooms in pairs or groups and use technology as a tool for learning."

Starting with minimizing class sizes while maximizing students' exposure time to English, can be the first practical step towards facilitating this shift. The number of students in some classrooms in Saudi Arabia reaches 40-50, and even exceeds it in some schools. It is not practically possible to expect teachers to integrate enough cooperative learning activities into their teaching unless the number of students drops significantly. Moreover, exposing students to English for less than two hours a week in primary school and to around three hours a week in the intermediate and secondary school, which is the current practice in Saudi schools, is not remotely sufficient to advance students' English language proficiency to the desired level regardless of the teaching method used and how much ICTs are utilized in the learning-teaching process. The Ministry of Education in Saudi Arabia should stop considering English 'another school subject' that can be taught or learnt through typical instruction for 2 or 3 hours 
a week. Rather, the Ministry ought-to realize that English is taught in Saudi Arabia as a foreign language, which requires certain basic conditions to be met, e.g. reasonable class size, appropriate classroom setting, enough exposure, and appropriate teaching methodologies, without which raising the English language proficiency levels may prove very difficult if not impossible to achieve.

\subsection{The Future of EFL Assessment}

The Tatweer policy highlights the need for incorporating new forms of assessment and evaluation into the new Saudi curriculum. It emphasizes the importance of designing a new holistic system of evaluation, which includes a year-long ongoing formative evaluation of the skills taught in addition to the end of year summative evaluation for each school subjects including English. Furthermore, it urges for exploiting the expertise of all the stakeholders involved in the educational process to continuously reassess current evaluation tools and strategies in order to develop and apply new ways of assessment through the establishment of a national community dedicated to developing assessment techniques, then sharing them with the TEFL teachers nationwide (National Strategy for Public Education Development, 2012, p. 53).

Language achievement tests used in schools are normally meant to assess students' prior knowledge and the materials covered in a language course (McNamara, 2008). Hughes (1989), however, suggests that achievement tests should rather be based on the course objectives and the learning outcomes intended for each course. Holt (1994, p. 6, as cited in Rauf, 2015) stated that student assessment serves as an essential tool “to measure students' ongoing progress, to qualify them to enroll in academic programs, to verify program effectiveness, and to demonstrate learners' gains.” It is important to note that the production of effective assessment tools that can produce the desired information is not an easy task and should not be taken lightly. The qualities of language tests, e.g. reliability, validity with all its subordinate forms, authenticity, and impact, should not just be a part of the theoretical knowledge of English language teachers, but need to be applied in all the language tests designed and administered inside the EFL classroom. Washback, which is defined as the effect that testing has on teaching and learning, is also one of the important consequences of testing that need constant weighing (Hughes, 1989). A major reason for the mismatch between the high students' scores in English in Saudi schools and their poor English skills and abilities may be the inadequate and poor-quality tests utilized for the assessment of English proficiency.

One important aspect of testing which is currently neglected in most Saudi schools is the diagnostic aspect. Self-assessment which can be reported by students as well as other diagnostic language tests, and which teachers can carry out inside a classroom to identify students' L2 weaknesses, can facilitate teaching and inform future interventions (Alderon, Brunfaut \& Harding, 2015). Such diagnostic tests can become an important link in the process of the English curriculum development cooperation discussed earlier between the different stakeholders, i.e. students, teachers, different education directorates and eventually the MOI. These tests can inform remedial reactions on both the teacher level, i.e. by developing and using the teaching materials and methodologies most appropriate to their students' levels and needs, and on the MOI level, i.e. by incorporating such feedback in the development and the overall curriculum. After all, the prime purpose of assessment is to elicit information that enables people to make informed decisions with beneficial consequences for stakeholders (Batchman \& Palmer, 2010, as cited in Rauf, 2015).

It is important to note that reliance on summative evaluation only, i.e. pass and fail, which is made at the end of the year, is not a favourable method of assessment especially in language learning classes. Formative evaluation, on the other hand, which is carried out throughout the language course and is affected by students' progress and performance helps in adjusting "learning and teaching while they are happening” (Garrison \& Ehringaus, 2007, p. 1), and serves the purpose of assessing the students' English developing language skills more validly and reliably. Nevertheless, a combination of the two, in which each of these two forms of assessment feeds back into the other as well as incorporating ICT based forms of language testing in conjunction with other forms of alternative assessments, e.g. students' portfolios and task-based and project-based language learning, may render as an even more valid and reliable way of assessing the students' achievement and proficiency in a second language course. As a rule of thumb, it is important for language teachers to remember that "in order for students to develop their language skills, English programs demand frequent assignments, a high level of formative assessment and detailed, supportive feedback” (Rauf, 2015, p. 204).

\subsection{Policy and Planning}

In comparison with other nations around the world, Saudi Arabia is still at its infancy stages with regard to developing and utilizing CALL and e-learning programs in general. The first Saudi Electronic University was only established in 2011. Yet, the Tatweer project emphasizes the importance of incorporating ICT into the future teaching systems in all school levels. The Saudi educational system is in a dire need for moving from the policy formulation phase to the policy implementation and evaluation stages since written policies have had no actual impact on TEFL reality, nor is it expected to have any future influence on the teaching trends without proper application and evaluation procedures. Even after 
appropriately training teachers on the effective strategies and practices of English instruction and technology-enhanced teaching, the MOE needs to ensure that adequate levels of resourcing are available in schools with regard to hardware, software and network infrastructure. After all, even the best trained teachers can only do so much without the necessary resources before losing their motivation for incorporating their newly acquired teaching skills and strategies into their instruction, and falling back into their old teaching practices and habits. Special in-school ICT assistance units also need to be established to offer assistance to inexperienced teachers on the use of the relevant ever-emerging technologies and to provide technical support when needed (Selinger \& Austin, 2003; Tawalbeh, 2001).

Moreover, in line with Bottino's (2003) statement that "policies should move from technology push, i.e. policies to make the technology available, to "demand-pull", i.e. polices driven by users' needs and pedagogical usefulness (p. 45), MOE should combine its efforts and resources to guide its policy formulation, implementation, and evaluation by establishing a specialized unit for the designing and enactment of policies. This unit may be made up of MOE planners, teaching methodologists and researchers as well as experienced teachers and principals collaborating to design, implement and evaluate current and future TEFL policies. Kettunen (2011) opined that the curriculum developed and used by students should stem from their own needs and the needs of the industries that will hire them after graduation, and should be delivered using methodologies consistent with the students' learning preferences. It is recommended that schools attempt to understand what needs to be done in order to improve the quality of education and learning outcomes based on the perspectives of the different stakeholders. This can be achieved through surveys and internal audits which can later be reported to MOE planners for consideration before and during the formulation of the new educational policies; then, strategizing appropriate action and evaluation plans, which can pave the way of actualizing the desired goals.

Quality assurance is one other aspect that needs special attention when designing any curriculum. Elyas and Al-Garni proposed that Biggs' (2003, 2014, as cited in Elyas \& Al-Garni, p. 162) constructive alignment model, which "integrates constructivist learning theory and instructional design practice", can be a useful approach of systematic development of ICT enhanced and distance learning curricula in the Saudi context. This approach attempts to describe the intended learning outcomes for each unit as a first step. These learning outcomes need to be clear and relevant to the final expected outcomes of the curriculum and based on the needs of stakeholders involved. The following step is to create the suitable environment and teaching-learning activities that are aligned with these specific learning outcomes and needed for accomplishing them. The final stage of this model is to construct the evaluation and assessment methods and tasks that are again closely aligned with the intended learning outcomes and translating their results into grades reflecting the extent of achievement of each of the intended learning outcomes.

Elyas and Al-Garni (2015) postulated that the constructive alignment could guide curriculum design best in conjunction with other models, such as Oliver and Harrington's (2001) and Churchill, King, and Fox's (2013) Resources-Activity-Support-Evaluation e-learning curriculum design models, which pay specific attention to task-based learning designs and activities, keeping track of the students' learning experiences, evaluation of the usefulness of content and the potential of using technological resources in delivering it, as well as the assessment of students' levels of achievement. These models have been applied across a wide range of contexts around the world, and have the potential of offsetting the problems that the previous and current English curriculums in the Saudi educational system have been prone to. They could also offer a fruitful direction towards the development of future English language curriculum that stems from the needs of the different stakeholders involved, and is empowered by the proper classroom setting and required facilities, teaching and learning activities, as well as assessment tasks specifically designed to cater for such needs in hopes of accomplishing the desired learning outcomes.

\section{Conclusions}

The advancement of English education in Saudi Arabia needs to be built on a culture that promotes respect for and interaction among practitioners, academics, curriculum designers, and policy makers in the Saudi educational system. Al-Roomi, the head of Tatweer project, asserts that collective and joint efforts are the key for success of the project (Al-Roomi, 2008, as cited in Elyas and Al-Ghamdi, 2018). It is important to remember that what is needed for the development of English education is not simply a push towards technology-enhanced learning and teaching practices, albeit an important step towards keeping up with the knowledge and skills needed to achieve a competitive edge in the 21st century, but instead an appropriate incorporation of effective teaching methods which foster both critical thinking and cooperative learning. What is additionally needed is a continual dialogue among the policy makers, scholars and practitioners "over how to conceptualize aspects of practice that support practitioner learning of high-quality instruction" (McDonald et al., 2013, p. 381). What also becomes important is an ongoing evaluation not just of mechanistic implementation of a set of suggested policies, but of the kinds of required teaching-learning settings that can be designed for both students and teachers to thrive. 


\section{Acknowledgements}

This project was funded by the Deanship of Scientific Research (DSR) at King Abdulaziz University, Jeddah, under grant no. (J- 37-125-39). The authors, therefore, acknowledge with thanks DSR for technical and financial support.

\section{REFERENCES}

[1] Abanomey, A. A. (2013). Do EFL Saudi learners perform differently with online reading? An exploratory study. Journal of King Saud University-Languages and Translation, 25, 1-11.

[2] Al-Abdulkareem, R. (2002). Future school: the main changes. Retrieved May 13, 2015 from http://www.psso.or g.sa/arabic/pssolibrary/nadwa03/papers/nadwat09.pdf

[3] Albalawi, M. S. (2007). Critical factors related to the implementation of web-based instruction by higher-education faculty at three universities at the kingdom of Saudi Arabia. Unpublished doctoral dissertation. The University of West Florida, Pensacola, Florida.

[4] Alderon, J. C., Brunfaut, T., \& Harding, L., (2015). Toward a theory of diagnosis in second and foreign language assessment: Insights from professional practice across diverse fields. Applied Linguistics, 36(2), 236-260.

[5] Al-Hadlag, A. (1998). Suggested strategy for ICT use as educational technology. King Saud University Journal of Islamic and Educational Studies, 10(2), 167-214.

[6] Al-Harby, H. (2014, April 13-15). Towards Successful Implementation of ICT in Education. Paper presented at WEI International Academic Conference, Vienna, Austria.

[7] Al-Jabry, H., Salahuddin, M., \& Al-Shazly, A. (2014). Developing and Piloting a Literature Course Learnable Via Blackboard for EFL Literature Instruction. Studies in Literature and Language, 8, 85-95.

[8] Al-Jarf, R. (2002). Effect of online learning on struggling ESL college writers. ERIC Document Reproduction Service No. ED47592. Http://eric.ed.gov/?id=ED489964

[9] Al-Jarf, R. (2004). The effect of web-based learning on struggling ESL college writers. Foreign Language Annals, 37(1), 46-56.

[10] Al-Jarf, R. (2015). Assessing EFL college instructors' performance with digital rubrics. In A. K. Hamdan (Ed.), Teaching and learning in Saudi Arabia: Perspectives from higher education (pp. 1-30). Rotterdam: Sense Publishers.

[11] Aljohani, K. (2006). ICT in Saudi secondary schools: from here to where? Unpublished master dissertation, Nottingham University.

[12] Al-Qahtani, M. (2006). Futuristic vision for developing the structure of Saudi secondary education system for boys in light of international experiences, Unpublished doctoral thesis, Umm Al-Qura University.
[13] Al-Madani, F. M., \& Allaafiajiy, I. A. (2014, June) Teachers' professional development on ICT use: A Saudi sustainable development model. Proceeding of the 2nd International Conference on Social Sciences Research ICSSR 2014, Kota Kinabalu, Sabah.

[14] Al-Mekhlafi, A. G. (2006). The effect of computer-assisted language learning (CALL) on United Arab Emirates English as a foreign language school student's achievement and attitude. Journal of Active Learning Research, 17(2), 121-142.

[15] Al-Mukhallafi, T. R. (2014). Computer Assisted Language Learning for Learning English in Saudi Arabia. Unpublished doctoral thesis. University of Technology, Sydney.

[16] Al-Saleh, B. (2002, 22-23 October). Technology and schools in the future: myths and facts. Paper presented at the Schools in the Future Conference, Saudi Arabia, Riyadh, King Saud University.

[17] Al-Sheikh, M. H. (2015). Cooperative learning: A case for creative and efficient teaching and learning. In A. K. Hamdan (Ed.), Teaching and learning in Saudi Arabia: Perspectives from higher education (pp. 101-119). Rotterdam: Sense Publishers.

[18] Al-Showaye, M. (2002). Use of computer-based information technology and the Internet in Saudi Arabian intermediate and secondary schools, Unpublished doctoral thesis, University of Manchester.

[19] Alshumaim, Y., \& Alhassan, R. (2010). Current Availability and Use of ICT among Secondary EFL Teachers in Saudi Arabia: Possibilities and Reality. Paper presented at the Global Learn Asia Pacific 2010, Penang, Malaysia. http://www.editlib.org/p/34227 (Galosh, 2011).

[20] Alshumaimeri, Y. (2008). Perceptions and attitudes towards using CALL in English among Saudi secondary EFL Teachers. The JALT CALL Journal, 4(2), 29-46.

[21] Amara, R. (1981). The futures field: Searching for definitions and boundaries. The Futurist, 15(2), 25-29.

[22] Artzt, A., \& Newman, C. (1990). How to use cooperative learning in the mathematics class. Reston, VA: National Council of Teachers of Mathematics.

[23] Aviram, A. (2000). ICT and education: From computers in the classroom to mindful radical adaptation by education systems to the emerging cyber culture. Journal of Educational Change, 1(4), 331-352.

[24] Baines, E. (2005). Managing change: Getting ready for the twenty-first-century classroom. In M. Leask \& N. Pachler, (Eds.), Learning to teach using ICT in the secondary school: A companion to school experience (pp. 165-181). Routledge.

[25] Bawazeer, K. (2015). A system for teaching English in Saudi Arabia. In A. K. Hamdan (Ed.), Teaching and learning in Saudi Arabia: Perspectives from higher education (pp. 3148). Rotterdam: Sense Publishers.

[26] Bell, W. (2001). Futures studies come of age: twenty-five years after the limits to growth. Futures, 33, 63-76.

[27] Black, A. (2010). Gen Y: Who they are and how they learn. 
Educational Horizons, 88, 92- 101.

[28] Bottino, R. M. (2003). ICT, national policies, and impact on schools and teachers' development. Paper presented at the ICT and the Teacher of the Future.

[29] Churchill, D., King, M., \& Fox, B. (2013). Learning design for science education in the $21^{\text {st }}$ century. Journal of the Institute for Educational Research, 45(2), 404-421.

[30] Condie, R., \& Simpson, M. (2004). The impact of ICT initiatives in Scottish schools: cultural issues. European Journal of Teacher Education, 27, 73-82.

[31] Cuseo, J. (1992). Collaborative \& cooperative learning in higher education: A proposed taxonomy. Cooperative Learning and College Teaching, 2(2), 2-4.

[32] Davidson, N. (1990). The small-group discovery method in secondary and college-level mathematics. In N. Davidson (Ed.), Cooperative learning in mathematics: A handbook for teachers (pp. 335-361). Menlo Park, CA: Addison-Wesley.

[33] Elyas, T. \& Al-Garni, A. (2015). Curriculum design quality assurance of distance education. In A. K. Hamdan (Ed.), Teaching and learning in Saudi Arabia: Perspectives from higher education (pp. 145-174). Rotterdam: Sense Publishers.

[34] Elyas, T. \& Al-Ghamdi, A. (2018), A Critical "Positivist" Analysis of Tatweer Policy in Saudi Arabia, in Alexander W. Wiseman, Petrina M. Davidson (ed.) Cross-nationally Comparative, Evidence-based Educational Policymaking and Reform (International Perspectives on Education and Society, Volume 35) (pp. 241-276). Emerald Publishing Limited.

[35] Fageeh, A. I. (2014). Effects of Using the Online Dictionary for Etymological Analysis on Vocabulary Development in EFL College Students. Theory and Practice in Language Studies, 4(5), 883-890.

[36] Fageeh, A., \& Mekheimer, M. (2013). Effects of blackboard on EFL academic writing and attitudes. The JALT CALL Journal, 9(2), 169-196.

[37] Garrison, G., \& Ehringaus, M. (2007). Formative and summative assessments in the classroom. Retrieved February 20, 2015 from http://www.amle.org/Publications/ WebExclusive/Assessment/tabid/1120/Default.aspx

[38] Galusha, J. (2011). Barriers to learning in distance education. Hattiesburg, MI: University of Southern Mississippi Press.

[39] General Directorate for Planning. (2005). The executive summary of the Ministry of Education ten- year plan 1425 1435 H (2004-2014), Ministry of Education.

[40] Grossman, P. (2008). Back to the future: Directions for research in teaching and teacher education. American Educational Research Journal, 45, 184-205.

[41] Haapala, A. (2000). Futures education in Finnish national framework curriculum for the comprehensive school. Paper presented at the European Conference on Educational Research.

[42] Hicks, D. (2002). Lessons for the Future: The missing dimension in education. Routledge, London.
[43] Hughes, A. (1989). Testing for language teachers. Cambridge, UK: Cambridge University Press.

[44] Hutchinson, T., \& Waters, A. (1987). English for specific purposes: A learning-centred approach. Cambridge, England: Cambridge University Press.

[45] Iakovos, T. (2011). Critical and creative thinking in the English language classroom. International Journal of Humanities and Social Science, 8, 82-86.

[46] Ibrahim, A. H., \& Yusoff, Z. S. (2012). Teaching public speaking in a blended learning environment. International Journal of Social Science and Humanity, 2(6), 573-576.

[47] Jelfs, A. \& Whitelock, D. (2000). The notion of presence in virtual environments: what makes the environment "real." British Journal of Educational Technology, 31(2), 145-153.

[48] Johnson, D., Johnson, R., \& Smith, K. (1991). Cooperative learning: Increasing college faculty instructional productivity, ASHE-ERIC Higher Education Report No. 4, Washington, DC: The George Washington University.

[49] Kettunen, J. (2011). Strategy and quality maps in higher education. US-China Education Review, 8(2), 149-156.

[50] Levin, I., \& Kojukhov, A. (2013). Personalization of Learning Environments in a Postindustrial Class. In M. Patrut \& B. Patrut (Eds.), Social media in higher education: Teaching in Web 2.0. (pp. 105-123). Idea Group Inc (IGI).

[51] Lonn, S., \& Teasley, S. D. (2009). Saving time or innovating practice: Investigating perceptions and uses of learning management systems. Computers \& Education, 53(3), 686-694.

[52] McDonald, M., Kazemi, E, \& Kavanagh, S. (2013). Core practices and pedagogies of teacher education: A call for a common language and collective activity. Journal of Teacher Education, 20(10), 1-9.

[53] McNamara, T. (2008). Language testing. In H. G. Widdison (Ed.), Oxford introductions to language study. Oxford, UK: Oxford University Press.

[54] Mercer, D. (1999). Lifelong learning is the future: opportunities for education providers. Foresight, 1(2), 125-130.

[55] OECD (2001). Schooling for tomorrow: what schools for the future? OECD, France.

[56] Oliver, R., \& Harrington, J. (2001). Teaching and learning online: A beginner's guide to e learning and e-teaching in higher education. Centre for Research in Information Technology and Communications. Edith Cowan University Press.

[57] Parris, H., Estrada, L., \& Honigsfeld, A. M. (2016). ELL frontiers: Using technology to enhance instruction for English learners. Thousand Oaks, CA: Corwin.

[58] Rauf, M. (2015). Best practices in English language testing at the university preparatory year programs. In A. K. Hamdan (Ed.), Teaching and learning in Saudi Arabia: Perspectives from higher education (pp. 85-205). Rotterdam: Sense Publishers.

[59] Reddy, Y., \& Andrade, H. (2010). A review of rubric use in higher education. Assessment \& Evaluation in Higher 
Education, 35(4), 435-448.

[60] Roblyer, M. D., \& Doering, A. H. (2010). Integrating educational technology into teaching (5th ed.). New York: Allyn \& Bacon.

[61] Sayed-Mouchaweh, M., \& Lughofer, E. (2012). Introduction in learning in non-stationary environments. London, England \& New York, NY: Pearson.

[62] Schieble, M., Vetter, A., \& Meacham, M. (2015). A discourse analytic approach to video analysis of teaching: Aligning desired identities with practice. Journal of Teacher Education, 66(3), 245-260.

[63] Selinger, M., \& Austin, R. (2003). A comparison of the influence of government policy on information and communications technology for teacher training in England and Northern Ireland. Technology, Pedagogy and Education, 12, 19-38.

[64] Stephens, D. (2007). Quality issues in distance learning. Tampa, FL: The Association of Advance Collegiate Schools of Business.

[65] Tawalbeh, M. (2001). The policy and management of information technology in Jordanian schools. British Journal of Educational Technology, 32, 133-140.

[66] Wasserman, E., \& Millgram, Y. (2005). Changes in the approaches of teachers following computerization of schools. Journal of Educational Computing Research, 32, 241- 264.

[67] Weast, J., Wright, J. S., \& Frye, S. (1996). Raising teacher performance by improving teacher evaluation: Guilford County's project H.E.L.P. ERS Spectrum, 14(3), 3-8.

[68] Widdowson, H. (1983). Defining issues in English language teaching. Oxford, England: Oxford University Press.

[69] Yonghong, C., \& Chongde, L. (2006). Theory and practice on teacher performance evaluation. Frontiers of Education in China, 1, 29-39.

[70] Zeichner, K., Payne, K. A., \& Brayko, K. (2015). Democratizing teacher education. Journal of Teacher Education, 66(2), 122-135. 